\title{
Consumer Preferred Hot Beverage Temperatures
}

\author{
Carl P. Borchgrevink* \\ Michigan State University \\ Alex M. Susskind \\ Cornell University \\ John M. Tarra \\ Michigan State University
}

\author{
February 27, 1998
}

*Carl P. Borchgrevink (corresponding author), The School of Hospitality Business, Michigan State University, East Lansing, MI 48824. Tel.: 1-517-353-9211; Fax: 1-517-4321170; E-mail: carlb@pilot.msu.edu

Alex M. Susskind, The School of Hotel Administration, Cornell University, Ithaca, NY 14853.

John M. Tarra, The School of Hospitality Business, Michigan State University, East Lansing, MI 48824 


\begin{abstract}
The hospitality and food science literatures specify brewing and holding temperatures for hot beverages such as coffee, while the medical literature states that those very beverage temperatures will cause scalds and harm. These two specifications are at odds with one another, and recommend different approaches to serving and handling hot beverages. Considering the disparate standards it is interesting to note that no one has reported asking consumers of hot beverages at which temperature they prefer to consume their hot beverages. This pilot study is a first step in determining the consumer preferred hot beverage temperature. The research intent is to see if a temperature, or temperature range, can be established at which consumers drink a hot beverage, in this case coffee. The research is particularly relevant given recent litigation relative to spills and burns at foodservice operations, and subsequent changes in holding temperatures at some quick service restaurant chains. The findings suggest that the standard brewing and holding temperatures are too high for consumption, while the temperature identified as the medical literature threshold for burns is too low for consumption.
\end{abstract}

Keywords: Temperature; Beverages; Drinks; Consumer 


\section{Consumer Preferred Hot Beverage Temperatures}

\section{Introduction}

The coffee tree is indigenous to tropical Africa where the fruit was initially used to produce a 'wine' like beverage, while the seeds, today known as coffee beans, were used as a food and stimulant (McGee, 1984). The earliest written reference to coffee is found in a source dated to the 9th century AD; coffee was administered as a drug in $1000 \mathrm{AD}$ by an Arabic man of medicine called Avicenna (Lavazza, 1991).

Crushing and pulverizing roasted beans and whipping the ensuing powder into hot water, was how coffee was initially made (McGee, 1984). Although the process has changed somewhat, the temperature of the brewing water remains a central issue. Brewing water needs to be "hot"' in order to extract sufficient soluble solids to produce adequate body. The hotter the water, the more soluble solids are extracted. As the temperature of the brewing water increases, the beverage becomes increasingly bitter, and loses aroma and carbon dioxide. The grind of the beans also plays a role, in that the finer the grind the quicker the soluble components are extracted, shortening the requisite brewing time. Thus the various brewing methods have different ideal grinds.

The ideal beverage is considered to be a brew that has extracted $18-22 \%$ by weight of the solids in the grind (Charley \& Weaver, 1998; McGee, 1984). Under extraction produces a weaker and somewhat sour tasting beverage, as the acids in the bean are among the first to dissolve, while overextraction (22$30 \%$ ) produces an overly bitter tasting beverage. To obtain the ideal extraction, the temperature of the water used in brewing coffee should minimally be $85^{\circ} \mathrm{C}\left(185^{\circ} \mathrm{F}\right)$, and maximally be $95^{\circ} \mathrm{C}\left(203^{\circ} \mathrm{F}\right)$ (Charley \& Weaver, 1998; CIA, 1995; Gisslen, 1995; Lavazza, 1991; McGee, 1984; Molt, 1997). It should be added that taste is socially constructed and that individual consumers may prefer beverages at higher or lower rates of extraction; espresso which is increasing in popularity may have extraction rates as high as $25 \%$.

Under ideal conditions the coffee would be consumed shortly after brewing. Charley and Weaver (1998) suggest that the quality of brewed coffee will improve if it is held for a three-minute ripening 
period, but that flavor loss occurs thereafter. Circumstances are often not ideal, and coffee may be held for a period of time beyond the prescribed three minutes. The general rule of thumb is that coffee can be held 15-20 minutes in small 8-12 cup pots with a heating source under the pot without noticeable loss of quality. In coffee urns, the coffee can be held up to one hour, while coffee held in insulated serving decanters can be held beyond one hour, and still maintain quality. In the hospitality literature (see for example: Gisslen, 1995 or Molt, 1997) the recommended holding temperature range is $85-88^{\circ} \mathrm{C}(185-$ $\left.190^{\circ} \mathrm{F}\right)$. In food science we have found a somewhat higher recommended holding temperature, viz., $93^{\circ} \mathrm{C}$ $\left(200^{\circ} \mathrm{F}\right)$ (Charley \& Weaver, 1998). Although they specify that this temperature is preferred over lower temperatures, they do not specify why they recommend said temperature. Higher holding temperature lead to more rapid decomposition of the coffee, resulting in poorer color, clarity, flavor, and sedimentary development. Thus, as holding temperature increases, holding time decreases.

In the medical literature, the above temperatures are considered potentially dangerous for all persons. This is particularly the case for the very young, for individuals that are intoxicated, and for individuals with altered mentation [sic] or behavior (Mellen, Golle, \& Smialek, 1995). Each of these groups would be considered high- risk groups relative to burns and scalds, as they may be unable to control the administration of food, solid or liquid. Mellen et al. (1995) point to a diagnosed schizophrenic who received fatal scald wounds upon rapid consumption of hot coffee. In addition to coffee, they identify microwave-heated liquids and pizza as potential hazards.

Skin can maximally dissipate heat at the rate of 0.04 calories per s per $\mathrm{cm}^{2}$ (Munster $\&$ Chiccone, 1985). The tolerance for heat is moderated to a degree by the skins water content, thickness, pigmentation, and circulation, as well as the presence of hair, oil, or dirt. Little or no damage occurs to skin that is exposed to temperatures at or below $44^{\circ} \mathrm{C}\left(111.2^{\circ} \mathrm{F}\right)$, unless the contact is for protracted periods of time. At $44^{\circ} \mathrm{C}\left(111.2^{\circ} \mathrm{F}\right)$ immersion or contact would have to be maintained for about $6 \mathrm{~h}$ for irreversible damage to occur. Thus, $44^{\circ} \mathrm{C}(111.2 \mathrm{~F})$ is considered the equilibrium point for normal skin. Between $44^{\circ} \mathrm{C}\left(111.2^{\circ} \mathrm{F}\right)$ and $51^{\circ} \mathrm{C}\left(123.8^{\circ} \mathrm{F}\right)$ the rate of cellular destruction doubles with each degree Centigrade rise in temperature. Between 60 and $65^{\circ} \mathrm{C}\left(140149^{\circ} \mathrm{F}\right)$ the rate of damage is ten million times 
greater than it is at $45^{\circ} \mathrm{C}\left(113^{\circ} \mathrm{F}\right)$, just beyond the equilibrium point. At temperatures beyond $70^{\circ} \mathrm{C}$ $\left(158^{\circ} \mathrm{F}\right)$ even extremely brief exposure will lead to total tissue destruction (Munster\& Chiccone, 1985; Moncrief, 1979).

In the United States, a significant amount of litigation has resulted from coffee spills at food service establishments, particularly quick service restaurants. The most notorious case is that of Stella Liebeck vs McDonalds Corporation, in which 2.7 million dollars were awarded in punitive damages; this amount was subsequently reduced to $\$ 480,000$, followed by an undisclosed settlement (Corley, 1998). In a more recent case, Nadel vs Burger King Corporation, (1997), the Court of Appeals in Ohio established coffee temperature as a liability standard. The court established that coffee may be found to be so hot that its risks outweighs its benefits. If such facts are established, and burns occur from said coffee, punitive damages may be relevant. Thus, the courts seem to suggest that the locus of control lies with the foodservice establishment, not with the consumer, and recent research (Rutherford, 1998) found that many quick service restaurants have lowered their holding temperatures. Although, according to the National Burn Victim Foundation (Harry J. Gaynor, pers comm, October 19, 1998) the coffee served at food service establishments is "still too hot for human consumption." Considering the above, it would appear that the temperatures specified as recommended temperatures by the hospitality and food science literatures for brewing and holding coffee are at odds with the medical literature's discussion of beverage temperatures that result in burns, permanent cellular damage, and death. Furthermore, the temperature of beverages served by foodservice operators has become a liability concern. With this is mind, the hospitality literature and related literatures were searched to see if this issue had been addressed, or if the consumer had been queried as to their preferred temperatures for hot beverage consumption. The only indication of awareness of consumer preferences was an editorial in the New York Times (3 January, $1995)$ which mentioned that experts in a coffee burn case specified $154^{\circ} \mathrm{F}\left(67.8^{\circ} \mathrm{C}\right)$ as sippable. The objective of this pilot study was to see if it is possible to establish a meaningful consumer preferred coffee consumption temperature, or whether preferences varied so much that a consumer preference standard could not be established. 


\section{Materials and methods}

Subjects

Subjects were 250 undergraduate students from two large public universities. The universities are located in the Midwest and the Southeast, respectively, and the data was collected throughout the spring and summer semesters. ${ }^{1}$ Junior level students were offered extra credit points if they chose to participate in the research. Approximately, 40 percent of the participants were female.

The students were recruited in their classes through overhead announcements and verbal communication of the extra credit opportunity of participating in some research. Given the nature of the research, the universities involved required that the students be presented with a statement of consent indicating that the research would focus on temperatures of hot beverages, and that they would be asked to judge the appropriateness of various temperatures of beverages presented to them. The consent form indicated that the temperatures they would be presented with were consistent with temperatures they may be exposed to at hospitality establishments. The consent form also contained the following clause:

"I understand that if I am injured as the result of my participation in this research project, [the university] will provide emergency medical care if necessary. I further understand that if the injury is not caused by the negligence of [the university] I am personally responsible for the expense of emergency care and any other medical expenses incurred as a result of this injury." Students self-selected to participate, and it is possible that the above clause led to a lowered participation rate. The make-up of the participants, however, was consistent with the make-up of the class and student body at large.

A questionnaire was designed to allow for the assessment of seven hot beverages. All subjects were told verbally as well as in written form the following:

"We will provide you with seven (7) cups of coffee, one cup at a time, and ask that you assess how appropriate you find the beverage temperature to be for drinking at its current temperature.

\footnotetext{
1 The different geographic locations and the spread in time should help ensure that season or weather did not influence the temperature preference. Moreover, the data were collected in rooms with climate control.
} 
Try it like you would try any cup of coffee or tea. If you normally use sugar or cream, we will not provide that, as that will impact the temperature. Please make your best assessment of the beverage temperatures as presented to you. As additional beverages are presented to you, do not assess them in comparison to previous beverages. You may be presented with a cup of beverage that has the same temperature, a higher temperature or a lower temperature than a previous beverage. Please take the time to consider your response carefully, as your honest opinion is most important to us."

Subjects evaluated seven cups of coffee. The coffee samples were served from insulated pitchers into 6 oz. Styrofoam cups. Each pour was approximately 4 ounces. Considering that foodservice operations control the brewing and holding temperature of coffee, the temperature was checked immediately before service rather than upon pouring. The temperature of the coffee in the insulated pitchers was confirmed immediately prior to service using digital instant read thermometers.

The subjects were allowed to choose from the available timeslots when they would participate in the research. As such the group size varied somewhat, ranging from 4-20. The beverage temperature sequence that the subjects were asked to assess was randomized for each group. The randomization of temperatures was done to minimize the potential of an order or undesired treatment effect. For example, subjects initially exposed to potentially scalding beverage may not be able to adequately assess lower temperature beverages; alternatively, subjects exposed to increasing temperatures may increase their tolerance.

All subjects were exposed to the following temperatures: $57.2^{\circ} \mathrm{C}\left(135^{\circ} \mathrm{F}\right), 62.8^{\circ} \mathrm{C}\left(145^{\circ} \mathrm{F}\right), 68.3^{\circ} \mathrm{C}$ $\left(155^{\circ} \mathrm{F}\right), 73.9^{\circ} \mathrm{C}\left(165^{\circ} \mathrm{F}\right), 79.4^{\circ} \mathrm{C}\left(175^{\circ} \mathrm{F}\right), 85^{\circ} \mathrm{C}\left(185^{\circ} \mathrm{F}\right)$, and $90.6^{\circ} \mathrm{F}\left(195^{\circ} \mathrm{F}\right)$. The subjects were served one beverage at a time, and required to record their response on the questionnaire prior to receiving the next beverage sample. Fresh cups were used for each pour, and the subjects were not permitted to discuss the temperature of the beverage, or any other issue relative to coffee or tea service. Before each fresh pour, any remaining samples were removed. All subjects received black coffee and were required to make their assessment without condiments of any sort. The available questionnaire responses were "Far too 
hot," "Somewhat too hot," "Just the right temperature," "Somewhat too cold," "Far too cold," coded from 5 to 1 , respectively.

Analysis

Data were analyzed using SPSS 7.5 for Windows (SPSS, 1997). Using the descriptive option, mean preference scores were established for each coffee temperature. Mean intervals were established at 95\% confidence. Given the geographic disparity of the two sub-samples, the data was grouped according to geographic origin. Levene's test for equality of variance was run for each preference score followed by an independent sample t-test for mean difference between the Midwest and Southeast temperature preferences. Confidence intervals $(p=0.05)$ were established for the grouped means as well.

\section{Results}

Two hundred and fifty subjects took part in the research, and we obtained a valid $n=247$ using listwise deletion. The maximum and minimum number of responses per beverage temperature is 248 and 249 , respectively. Table 1 contains the overall results in a summary fashion. A score of " 3 " is indicative of a beverage temperature that is consider to be "just right" for consumption at its current temperature. According to this study, the ideal temperature for consumption lies within the range of $62.8^{\circ}-68.3^{\circ} \mathrm{C}$ $\left(145^{\circ}-155^{\circ} \mathrm{F}\right)$, consistent with the report in the New York Times (3 January, 1995) mentioned above. The confidence intervals for the mean preference scores overlap for $85^{\circ} \mathrm{C}\left(185^{\circ} \mathrm{F}\right)$, and $90.6^{\circ} \mathrm{F}\left(195^{\circ} \mathrm{F}\right)$.

When mean scores were established with geographic origin as grouping variable, mean differences were observed between the two groups. Levene's test for equality of variance was rejected for all temperatures but $62.8^{\circ} \mathrm{C}\left(145^{\circ} \mathrm{F}\right)$ and $68.3^{\circ} \mathrm{C}\left(155^{\circ} \mathrm{F}\right)$. The t-test for equality of means was rejected for all temperatures but $62.8^{\circ} \mathrm{C}\left(145^{\circ} \mathrm{F}\right)$ and $73.9^{\circ} \mathrm{C}\left(165^{\circ} \mathrm{F}\right)$. The confidence intervals for each geographic group confirm the overall ordinal ranking, however. Furthermore, both groups display a confidence interval overlap for $85^{\circ} \mathrm{C}\left(185^{\circ} \mathrm{F}\right)$, and $90.6^{\circ} \mathrm{F}\left(195^{\circ} \mathrm{F}\right)$, respectively. In addition, the Midwest sample has 
overlapping confidence intervals at $68.3^{\circ} \mathrm{C}\left(155^{\circ} \mathrm{F}\right)$ and $73.9^{\circ} \mathrm{C}\left(165^{\circ} \mathrm{F}\right)$. Please see Table 2 for additional detail.

\section{Discussion}

This research suggests that the preferred temperature for consuming hot beverages such as coffee is considerably above the equilibrium point established by the medical literature, yet below the levels considered standard holding and brewing temperatures for coffee in the hospitality industry. The results indicate that coffee is ideally consumed when it is in the mid to upper part of the range of $62.8^{\circ}-68.3^{\circ} \mathrm{C}$ $\left(145^{\circ}-155^{\circ} \mathrm{F}\right)$. The hospitality industry recommended holding temperature for coffee, $85^{\circ} \mathrm{C}\left(185^{\circ} \mathrm{F}\right)$, received an average score of 4.6 , as did the highest beverage temperature used in this study $90.6^{\circ} \mathrm{C}$ $\left(195^{\circ} \mathrm{F}\right)$. The latter is below the recommended holding temperature identified in the food science literature, yet within the range of acceptable brewing temperatures. We did not measure the acceptability of beverages beyond $90.6^{\circ} \mathrm{F}\left(195^{\circ} \mathrm{F}\right)$. Given the findings, it is likely that such temperatures would be considered even less appropriate for consumption. The 95\% confidence intervals of the rating of the two highest temperature points overlap, both for the overall sample (See Table 1) as well as for the geographically grouped samples (See Table 2). This confirms that the mean responses for these two temperatures are not significantly different. Additionally, the Midwest sample did not note significantly different responses for $68.3^{\circ} \mathrm{C}\left(155^{\circ} \mathrm{F}\right)$ and $73.9^{\circ} \mathrm{C}\left(165^{\circ} \mathrm{F}\right)$. None of the other mean confidence intervals overlap. This suggests that they are perceived differently in terms of their appropriateness for consumption. The confidence intervals of the mean responses for the four lowest temperatures overlap; this suggests that there are no regional differences in preference for these four temperatures. For the three highest temperatures, however, the confidence intervals of the regional means do not overlap, suggesting that the two regional samples perceive the temperatures differently in terms of appropriateness. The Midwest sample perceive each of these temperatures as somewhat less preferable than the Southeast sample. None-the-less, the ordinal ranking of temperatures is consistent across the two regional subsamples (see Table 2). It would be tempting to suggest that the relatively warmer climate of the 
Southeast compared to that of the Midwest may lead to an increased acceptance of warmer coffee temperatures. Given the sample size and the fact that this is a pilot study, such conclusions are premature.

It is important to note, however, that although, $85^{\circ} \mathrm{C}\left(185^{\circ} \mathrm{F}\right)$ and $90.6^{\circ} \mathrm{C}\left(195^{\circ} \mathrm{F}\right)$ are not perceived as different from one another by the subjects within each region, or as a whole, they are nonethe-less both considered too hot for consumption. Indeed, even $79.4^{\circ} \mathrm{C}\left(175^{\circ} \mathrm{F}\right)$ was rated as "somewhat too hot', for consumption.

Furthermore, it is important to note that all assessments of temperature appropriateness were done as the beverage was presented to the subjects. That is, the beverages were presented for immediate consumption. Consumers at large may allow for a cooling period and modify the temperature with the addition of condiments. Although this may be seen as a departure from how coffee is consumed, given the intent of the study it was seen as the most reasonable approach: Measuring each individual subject's coffee just as it reached the "preferred temperature" would be difficult, except for very small samples. Furthermore, foodservice operators are able to monitor and control the holding temperature, and have less control over the temperature in the consumer's cup.

A limitation of the study is the relatively narrow characteristics of the sampling frame. All subjects were college students enrolled in hospitality business courses. Future research should be performed with a wider sampling frame, as it is possible that consumer groups other than those sampled may have different temperature preferences. For example, as consumers of coffee age, they may build a tolerance for warmer coffee. In addition, future research should investigate the temperature impact of various levels of condiments such as sugar, cream and milk, in a variety of cup sizes. Finally, the type of cup used may impact the temperature-Styrofoam cups, as in this test, maintain temperatures well, while a cold porcelain cup would lead to a drop in temperature.

Although, the recommended holding temperatures are perceived as too hot for consumption, it would be inappropriate to recommend that holding temperatures be reduced to a specific temperature at this time, but it is reasonable none-the-less to call for a reduction in standard holding temperatures. 
Table 1. Temperature preferences $(n=247)$

\begin{tabular}{rrrrrr}
\hline Temperatures & Minimum Score & Maximum Score & Mean & $\begin{array}{c}\text { Standard } \\
\text { Deviation }\end{array}$ & $\begin{array}{c}\text { 95\% } \\
\text { Confidence } \\
\text { interval } \\
(d \mathrm{f}=246)\end{array}$ \\
\hline $57.2^{\circ} \mathrm{C}\left(135^{\circ} \mathrm{F}\right)$ & 1.00 & 4.00 & 2.187 & 0.774 & $2.281-2.087$ \\
$62.8^{\circ} \mathrm{C}\left(145^{\circ} \mathrm{F}\right)$ & 1.00 & 5.00 & 2.643 & 0.761 & $2.735-2.544$ \\
$68.3^{\circ} \mathrm{C}\left(155^{\circ} \mathrm{F}\right)$ & 1.00 & 5.00 & 3.264 & 0.898 & $3.374-3.149$ \\
$73.9^{\circ} \mathrm{C}\left(165^{\circ} \mathrm{F}\right)$ & 2.00 & 5.00 & 3.682 & 0.758 & $3.779-3.589$ \\
$79.4^{\circ} \mathrm{C}\left(175^{\circ} \mathrm{F}\right)$ & 2.00 & 5.00 & 4.204 & 0.747 & $4.302-4.115$ \\
$85^{\circ} \mathrm{C}\left(185^{\circ} \mathrm{F}\right)$ & 3.00 & 5.00 & 4.590 & 0.629 & $4.670-4.512$ \\
$90.6^{\circ} \mathrm{C}\left(195^{\circ} \mathrm{F}\right)$ & 2.00 & 5.00 & 4.600 & 0.652 & $4.683-4.519$ \\
\hline
\end{tabular}


Table 2. Temperature preferences grouped $(n=247)$

\begin{tabular}{lllll}
\hline Temperature & $\begin{array}{l}\text { Midwest } \\
\text { mead SD } \\
(\mathrm{SD}) n=89\end{array}$ & $\begin{array}{l}\text { Southeast } \\
\text { Mean }(\mathrm{SD}) n \\
=158\end{array}$ & $\begin{array}{l}\text { Midwest } 95 \% \\
\text { Confidence } \\
\text { interval }\end{array}$ & $\begin{array}{l}\text { Southeast } \\
\text { Confidence } \\
\text { interval }\end{array}$ \\
\hline $57.2^{\circ} \mathrm{C}\left(135^{\circ} \mathrm{F}\right)$ & $\begin{array}{l}1.961 \\
(0.72)\end{array}$ & $\begin{array}{l}2.310 \\
(0.78)\end{array}$ & $2.109-1.812$ & $2.430-2.188$ \\
$62.8^{\circ} \mathrm{C}\left(145^{\circ} \mathrm{F}\right)$ & $\begin{array}{l}2.657 \\
(0.71)\end{array}$ & $\begin{array}{l}2.630 \\
(0.80)\end{array}$ & $2.804-2.511$ & $2.754-2.506$ \\
$68.3^{\circ} \mathrm{C}\left(155^{\circ} \mathrm{F}\right)$ & 3.433 & 3.165 & $3.584-3.281$ & $3.305-3.024$ \\
& $(0.73)$ & $(0.97)$ & & \\
$73.9^{\circ} \mathrm{C}\left(165^{\circ} \mathrm{F}\right)$ & $\begin{array}{l}3.697 \\
(0.66)\end{array}$ & $\begin{array}{l}3.677 \\
(0.81)\end{array}$ & $3.835-3.558$ & $3.803-3.551$ \\
$79.4^{\circ} \mathrm{C}\left(175^{\circ} \mathrm{F}\right)$ & $\begin{array}{l}4.523 \\
(0.52)\end{array}$ & $\begin{array}{l}4.032 \\
(0.79)\end{array}$ & $4.631-4.414$ & $4.155-3.908$ \\
$85^{\circ} \mathrm{C}\left(185^{\circ} \mathrm{F}\right)$ & 4.843 & 4.450 & $4.931-4.755$ & $4.556-4.343$ \\
& $(0.42)$ & $(0.68)$ & & \\
$90.6^{\circ} \mathrm{C}\left(195^{\circ} \mathrm{F}\right)$ & 4.747 & 4.520 & $4.852-4.642$ & $4.630-4.408$ \\
& $(0.51)$ & $(0.71)$ & & \\
\hline
\end{tabular}




\section{References}

Charley, H., \& Weaver, C. (1998). Foods: A Scientific Approach (3rd ed.) Upper Saddle River, NJ: Prentice Hall, Inc.

CIA (1995). The New Professional Chef (6th ed.). New York: Wiley.

Corley, E. T. (1998). Old Case - Still Hot. [On line] Available: http://www.corleyganem.com/summation.htm

Gisslen, W. (1995). Professional Cooking, (3rd ed.) New York: John Wiley \& Sons, Inc.

Lavazza, L., S.p.A. (1991). Lavazza Handbook 1 \& 2. Moncalieri, Italy: Lavazza.

McGee, H. (1984). On Food and Cooking (1st ed.). New York: Macmillan.

Mellen, P. F., Golle Jr, M. F., \& Smialek, J. E. (1995). Fatal hot coffee scald of the larynx: Case report. The American Journal of Forensic Medicine and Pathology, 16(2)), 117-119.

Molt, M. (1997). Food for Fifty (10th ed.) Upper Saddle River, NJ: Prentice Hall, Inc.

Moncrief, J. A. (1979). The body's response to heat. In C. P. Artz, J. A. Moncrief, \& B. A. Pruitt (Eds.), Burns: A Team Approach (pp. 23-44). Philadelphia, PA: W. B. Saunders Company.

Munster, A. M., \& Chiccone, T. G. (1985). Burns. In F. J. Dagher (Ed.), Cutaneous Wounds, Mount Kisco, NY: Futura.

New York Times (January 3, 1995). A simple pleasure, made complicated. The New York Times, 144, C3.

Rutherford, D. G. (1998). Lessons from Liebeck. Cornell Hotel and Restaurant Administration Quarterly, 59(3)), 72-75.

SPSS (1997). Statistical Program for the Social Sciences, v7.5. Chicago, IL: SPSS, Inc. 